\title{
Cerebral venetrombose med venøst infarkt
}
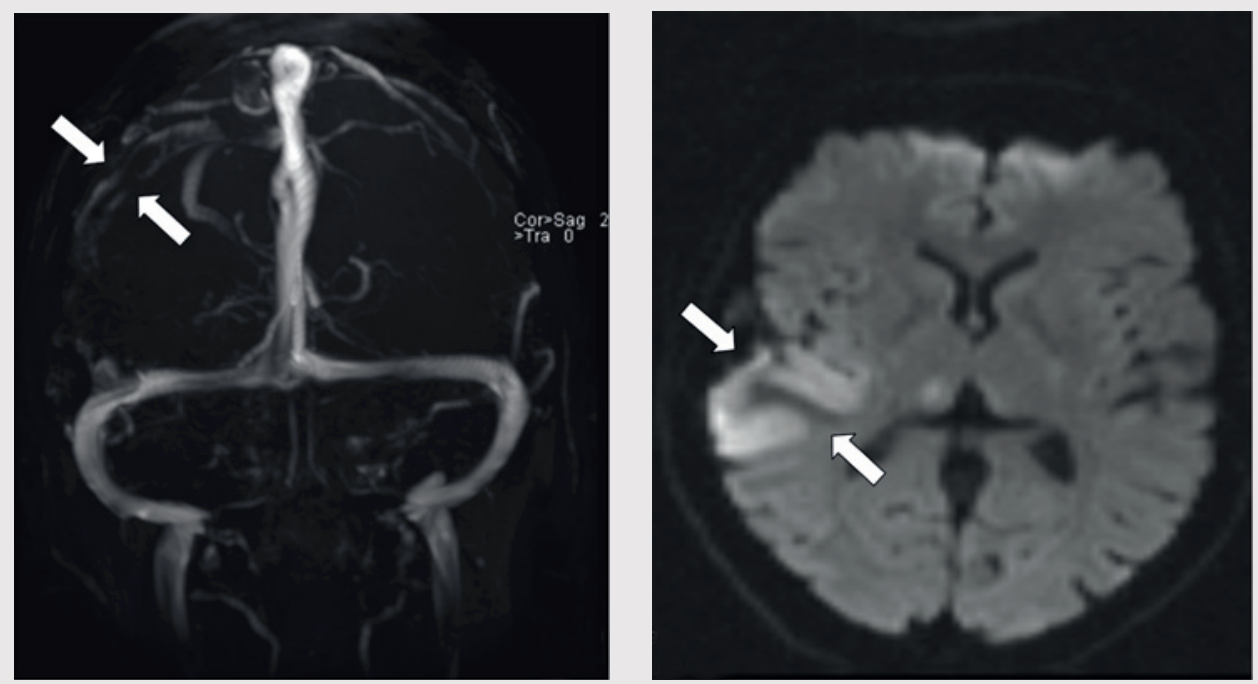

En tidligere frisk kvinne i 40-årsalderen hadde fra dagen før innleggelsen morgenhodepine og oppkast. Hun var ikke-røyker og brukte ingen medisiner eller hormoner. Innleggelsesdagen utviklet hun akutt parese i venstre ansiktshalvdel, venstresidig armparese og dysartri. Hun hadde forbigående rykninger i venstre ansiktshalvdel. Cerebral CT utført ved lokalsykehuset viste en høyattenuerende lesjon i høyre temporoparietallapp (bilde kun på nett). D-dimer var $0,8 \mathrm{mg} / 1$ (normalt $<0,4$ ). Man mistenkte vaskulær hendelse i høyre hemisfære. Cerebral MRvenografi ved universitetssykehuset dagen etter viste en intraluminal venøs fyllingsdefekt svarende til høyre vena Trolard (bildet til venstre). Diffusjonsvektet cerebral MR viste en blanding av vasogent og cytotoksisk ødem temporoparietalt, typisk for venøst infarkt (bildet til høyre). Testing av forstyrrelser i trombose-koagulasjonssystemet viste aktivert protein C-resistens 0,66 (normalt 0,85-1,15). Pasienten fikk antikoagulasjonsbehandling og seks dager etter initiering av antikoagulasjon var ny cerebral MRvenografi normalisert. Hun ble utskrevet uten sekvele.

Cerebral venetrombose gir ofte hodepine, og kan gi nevrologiske utfall og epileptiske anfall ved samtidig infarktutvikling. Aktivert protein $\mathrm{C}$-resistens disponerer for cere- bral venetrombose, som er en sjelden (0,5-1\%) årsak til hjerneslag (1). Rask diagnostikk og behandling er vesentlig for prognosen. CT- og MR-venografi kan med høy sensitivitet og spesifisitet ikke-invasivt visualisere venøse cerebrale tromber.

\section{Mirza Jusufovic}

mirzajus@hotmail.com

Nevrologisk avdeling

Klinikk for kirurgi og nevrofag

\section{Eva Astrid Jacobsen}

Nevroradiologisk seksjon

Avdeling for radiologi og nukleærmedisin

Christian Georg Lund

Nevrologisk avdeling

Klinikk for kirurgi og nevrofag

Oslo universitetssykehus, Rikshospitalet

Pasienten har gitt tillatelse til at artikkelen blir publisert.

Ett bilde finnes kun i Tidsskriftets nettutgave.

Mirza Jusufovic (f. 1980) er assistentlege ved Nevrologisk avdeling, Oslo Universitetssykehus, Rikshospitalet og har cerebrovaskulær sykdom som hovedinteresse.

Forfatter har fylt ut ICMJE-skjemaet og oppgir ingen interessekonflikter.
Eva Astrid Jacobsen (f. 1957) er dr.med. og arbeider som overlege, ved Avdeling for radiologi og nukleær medisin, Klinikk for diagnostikk og intervensjon, Oslo universitetssykehus. Hun er spesialist i radiologi med spesialkompetanse i nevroradiologi og nevrointervensjon. Forfatter har fylt ut ICMJE-skjemaet og oppgir følgende interessekonflikter: Hun har mottatt reisestøtte fra Codman.

Christian Georg Lund (f. 1961) er dr.med. og spesialist i nevrologi. Han er overlege ved Nevrologisk avdeling, Oslo universitetssykehus, Rikshospitalet og har cerebrovaskulær sykdom som hovedfelt.

Forfatter har fylt ut ICMJE-skjemaet og oppgir ingen interessekonflikter.

\section{Litteratur}

1. Johnsen HJ, Vorhaug A, Kvistad KA. Cerebral venetrombose - diagnostikk og behandling. Tidsskr Nor Lægeforen 2007; 127: 1069-73.

Mottatt 10.2. 2012, første revisjon innsendt 2.4 . 2012, godkjent 26.4. 2012. Medisinsk redaktør Jon Amund Kyte. 